\title{
Synthesis and Characterization of Pt-Ag Alloy Nanocages with Enhanced Activity and Durability towards Oxygen Reduction
}

Xuan Yang, ${ }^{\dagger}$ Luke T. Roling, ${ }^{\text {, }}$ Madeline Vara,${ }^{\S}$ Ahmed O. Elnabawy, ${ }^{\mathbb{T}}$ Ming Zhao, ${ }^{\S}$ Zachary D. Hood, ${ }^{\S, \dagger}$ Shixiong Bao, ${ }^{\dagger}$ Manos Mavrikakis, ${ }^{, \pi}$ and Younan Xia*, ${ }^{\dagger}, \S$

†The Wallace H. Coulter Department of Biomedical Engineering, Georgia Institute of Technology and Emory University, Atlanta, Georgia 30332, United States

IDepartment of Chemical and Biological Engineering, University of Wisconsin-Madison, Madison, WI 53706, United States

${ }^{\S}$ School of Chemistry and Biochemistry, School of Chemical and Biomolecular Engineering, Georgia Institute of Technology, Atlanta, Georgia 30332, United States

${ }^{\ddagger}$ Center for Nanophase Materials Sciences, Oak Ridge National Laboratory, Oak Ridge, TN 37831, United States

*Corresponding authors: manos@engr.wisc.edu (for computation) and younan.xia@bme.gatech.edu (for synthesis and electrochemical characterization) 


\section{Experimental Methods}

Chemical and Materials. Ethylene glycol (EG, $\geq 99.0 \%$ ) was purchased from J. T. Baker (Batch No. 0000034605). Silver trifluoroacetate $\left(\mathrm{CF}_{3} \mathrm{COOAg}, \quad \geq 99.99 \%\right)$, sodium hydrosulfide hydrate (NaHS $\left.1.5 \mathrm{H}_{2} \mathrm{O}\right)$, potassium tetrachloroplatinate(II) $\left(\mathrm{K}_{2} \mathrm{PtCl}_{4}, 99.99 \%\right)$, poly(vinyl pyrrolidone) (PVP, $\mathrm{MW} \approx 55,000)$, sodium chloride $(\mathrm{NaCl})$, sodium bromide $(\mathrm{NaBr})$, aqueous hydrochloric acid $(\mathrm{HCl}, 37 \%)$, and acetic acid $(99.7 \%)$ were all obtained from Sigma-Aldrich. Perchloric acid $\left(\mathrm{HClO}_{4}, 70 \%\right.$, PPT Grade, Veritas) was purchased from GFS chemicals. All chemicals were used as received. All aqueous solutions were prepared using deionized (DI) water with a resistivity of $18.2 \mathrm{M} \Omega \cdot \mathrm{cm}$.

Synthesis of Ag nanocubes. Silver nanocubes were synthesized using a protocol reported by our group. ${ }^{1}$ In a standard synthesis, $25 \mathrm{~mL}$ of EG were added into a flask and heated at $135{ }^{\circ} \mathrm{C}$ for $40 \mathrm{~min}$. Other reagents were separately dissolved in EG and sequentially introduced into the flask using a pipette. At first, $0.3 \mathrm{~mL}$ of $\mathrm{NaSH}$ solution $(3.5 \mathrm{mM})$ was added. After $4 \mathrm{~min}, 2.5 \mathrm{~mL}$ of $\mathrm{NaCl}$ solution $(3 \mathrm{mM}$ ) was introduced, followed by $6.25 \mathrm{~mL}$ of PVP solution $(20 \mathrm{mg} / \mathrm{mL}) 2 \mathrm{~min}$ later. After another $2 \mathrm{~min}, 2 \mathrm{~mL}$ of $\mathrm{CF}_{3} \mathrm{COOAg}$ solution $(282 \mathrm{mM})$ was added. At last, $2.5 \mathrm{~mL}$ of $\mathrm{NaBr}$ solution $(3 \mathrm{mM})$ was introduced after $5 \mathrm{~min}$ of delay. After another $15 \mathrm{~min}$, the synthesis was terminated by immersing the flask in an ice-water bath. The solution was equally divided into four portions, and $125 \mathrm{mg}$ of PVP was added into each fraction. This is necessary in order to prevent aggregation during the washing steps. The products were precipitated with acetone and collected by centrifugation at 6000 rpm for $10 \mathrm{~min}$, followed by washing with DI water twice to remove the remaining precursor, EG, and excess PVP.

Synthesis of Pt-Ag nanocages. In a standard synthesis of $\mathrm{Pt}-\mathrm{Ag}$ nanocages, $5 \mathrm{~mL}$ of $\mathrm{H}_{2} \mathrm{O}$, $0.33 \mathrm{~mL}$ of $\mathrm{HCl}(10 \mathrm{mM}), 0.5 \mathrm{~mL}$ of $\mathrm{PVP}(100 \mathrm{mM}, \mathrm{MW} \approx 55000)$, and $50 \mu \mathrm{L}$ of $\mathrm{Ag}$ nanocube suspension (particle concentration: $59 \mathrm{nM}$ ) were mixed in a $20 \mathrm{~mL}$ vial. The resulting solution was heated at $40{ }^{\circ} \mathrm{C}$ under magnetic stirring for $5 \mathrm{~min}$. Then, $0.4 \mathrm{~mL}$ of aqueous $\mathrm{K}_{2} \mathrm{PtCl}_{4}$ solution $(5 \mathrm{mM})$ was added using a syringe pump at a rate of $1 \mathrm{~mL} \mathrm{~min}{ }^{-1}$. The mixture was kept at $40{ }^{\circ} \mathrm{C}$ for another $5 \mathrm{~min}$ and then cooled to room temperature naturally. The final product was collected by centrifugation and washed with $\mathrm{H}_{2} \mathrm{O}$ three times, 
and then dispersed in DI water.

Structural and compositional analysis. TEM images were captured using a Hitachi HT7700 microscope operated at $120 \mathrm{kV}$ by drop casting the nanoparticle dispersions on carbon-coated $\mathrm{Cu}$ grids and drying under ambient conditions. High-angle annular dark-field and high-resolution TEM (HRTEM) imaging were performed on a JEOL JEM 2200FS STEM/TEM microscope equipped with a CEOS probe corrector (Heidelberg, Germany) to provide a nominal image resolution of $0.07 \mathrm{~nm}$. Energy-dispersive X-ray spectroscopy (EDX) elemental mapping was performed in the STEM mode on an aberration-corrected JEOL 2200FS electron microscope equipped with a Bruker-AXS SDD detector. The metal contents were measured using ICP-MS (NexION 300Q, Perkin Elmer). X-ray photoelectron spectroscopy (XPS) measurements were completed on each sample with a Thermo Scientific K-Alpha spectrometer. Each spectrum was collected with a spot size of $400 \mu \mathrm{m}$ and an operating pressure of less than $3.0 \times 10^{-7} \mathrm{~Pa}$ using an $\mathrm{Al} \mathrm{K} \alpha$ microfused monochromatized source $(1486.6 \mathrm{eV})$ with a resolution of $0.1 \mathrm{eV}$. The spectra were analyzed using the Avantage Data System, a software package available through Thermo Scientific. Attenuated total reflectance Fourier transform infrared (ATR-FTIR) spectroscopy experiments were performed using a Varian 640 FTIR spectrometer equipped with an internal reflection element made of diamond (angle of incidence $45^{\circ}$, three active reflections). Before the measurements, the crystal surface was washed using ethanol to remove any contaminants. The sample for analysis (about $10 \mu \mathrm{L}$ of colloidal solution containing the nanoparticles in ethanol) was cast-dropped on the top of the crystal and dried. Infrared spectra were recorded in the range of 4000-400 $\mathrm{cm}^{-1}$ with a resolution of $1 \mathrm{~cm}^{-1}$ using a cooled deuterated and L-alanine-doped triglycine sulfate (DLaTGS) detector. UV-vis absorption spectra were recorded with a Cary 60 spectrometer (Agilent Technologies).

Preparation of the working electrode. Firstly, the sample was loaded on a carbon support (Vulcan XC72 carbon) with a metal loading content of $20 \%$ based on the mass of $\mathrm{Pt}$ (determined by ICP-MS). The carbon-supported $\mathrm{Pt}-\mathrm{Ag}$ nanocages were then dispersed in 10 $\mathrm{mL}$ of acetic acid at room temperature for $3 \mathrm{~h}$ to clean the surface of the catalytic particles. The catalyst was recovered by centrifugation, followed by washing with ethanol twice and with DI water 10 times. After drying, $0.5 \mathrm{mg}$ of the catalyst was re-dispersed in a mixture of 
$0.8 \mathrm{~mL}$ of DI water, $0.2 \mathrm{~mL}$ of isopropanol, and $10 \mu \mathrm{L}$ of $5 \%$ Nafion under ultrasonication for $1 \mathrm{~h}$ to produce an ink with a Pt concentration of $0.07 \mathrm{mg} \mathrm{mL}^{-1}$ (measured by ICP-MS). $10 \mu \mathrm{L}$ of the suspension was then placed on a pre-cleaned glassy carbon rotating disk electrode (RDE, Pine Research Instrumentation) with a geometric area of $0.196 \mathrm{~cm}^{2}$ and dried at room temperature and under ambient conditions. The commercial Pt/C catalyst (20 wt\% $3.2 \mathrm{~nm} \mathrm{Pt}$ nanoparticles supported on Vulcan XC72 carbon, Premetek Co.) was used as a benchmark for comparison. Typically, $1 \mathrm{mg}$ of the $\mathrm{Pt} / \mathrm{C}$ catalyst was dispersed in a mixture of $0.8 \mathrm{~mL}$ of DI water, $0.2 \mathrm{~mL}$ of isopropanol, and $10 \mu \mathrm{L}$ of $5 \%$ Nafion under ultrasonication for $1 \mathrm{~h}$ to produce an ink with a Pt concentration of $0.20 \mathrm{mg} \mathrm{mL}^{-1}$ (measured by ICP-MS). $10 \mu \mathrm{L}$ of the ink was then placed on a pre-cleaned glassy carbon RDE and dried at room temperature and under ambient conditions.

Electrochemical measurements. Electrochemical measurements were conducted using a glassy carbon RDE connected to a $\mathrm{CHI} 600 \mathrm{E}$ potentiostat (CH Instruments). A Hydroflex hydrogen reference electrode (Gaskatel) and a Pt mesh were used as the reference electrode and counter electrode, respectively. All potentials were converted to values in reference to the reversible hydrogen electrode (RHE). The electrolyte was $0.1 \mathrm{M} \mathrm{HClO}_{4}$ prepared by diluting a $70 \%$ stock solution with DI water. The CV curve was recorded at room temperature in a $\mathrm{N}_{2}$-saturated $0.1 \mathrm{M} \mathrm{HClO}_{4}$ solution in the potential range of $0.08-1.1 \mathrm{~V}_{\mathrm{RHE}}$ at a scanning rate of $50 \mathrm{mV} \mathrm{s}^{-1}$. We calculated the specific ECSA of each catalyst based on the charges associated with the desorption of hydrogen in the region of $0.08-0.45 \mathrm{~V}_{\mathrm{RHE}}$ after double-layer correction with a reference value of $210 \mu \mathrm{C} \mathrm{cm}^{-2}$ (for commercial $\mathrm{Pt} / \mathrm{C}$ and $\mathrm{Pt}-\mathrm{Ag}$ nanocages) for the desorption of a monolayer of hydrogen from Pt surfaces. We measured the ORR activities of catalysts at room temperature in the potential range of $0.08-1.1 \mathrm{~V}_{\mathrm{RHE}}$ in an $\mathrm{O}_{2}$-saturated $0.1 \mathrm{M} \mathrm{HClO}_{4}$ solution through the RDE method at a scanning rate of $10 \mathrm{mV} \mathrm{s}^{-1}$ (rotating rate of 1,600 rpm). The background current is measured in the potential range of $0.08-1.1 \mathrm{~V}_{\mathrm{RHE}}$ by running the ORR sweep profile in an $\mathrm{N}_{2}$-saturated $0.1 \mathrm{M} \mathrm{HClO}_{4}$ solution at a scanning rate of $10 \mathrm{mV} \mathrm{s}^{-1}$ (rotating rate of 1,600 rpm). The ORR data were corrected by ohmic $i \mathrm{R}$ drop compensation and background currents.

For the accelerated durability test, we performed CVs and ORR polarization curves after sweeping different cycles $(5,000,10,000,20,000$, and 30,000 cycles) in the range of 0.6 and 
1.1 $\mathrm{V}_{\mathrm{RHE}}$ at a rate of $0.1 \mathrm{~V} \mathrm{~s}^{-1}$ in an $\mathrm{O}_{2}$-saturated $0.1 \mathrm{M} \mathrm{HClO}_{4}$ solution at room temperature. For the data shown in Figure 4A, the measurements were conducted with different samples of the same catalyst. After a sample had undergone a specific number of potential cycling, the metal particles were removed from the electrode by sonication. The recovered particles (together with some carbon) were dissolved in $1 \mathrm{~mL}$ of aqua regia and then diluted by 10 times for ICP-MS measurement.

DFT calculations. All calculations were performed using the Vienna ab initio Simulation package (VASP), ${ }^{2,3}$ a density functional theory code. The frozen core approximation was implemented using projector augmented wave (PAW) potentials, ${ }^{4,5}$ and the electron density was described using the GGA-PW91 exchange correlation functional. ${ }^{6}$ The electron wave function was expanded in a basis of plane waves, truncated at a $400 \mathrm{eV}$ kinetic energy cutoff. The calculated lattice constants of Pt and Ag are $3.99 \AA$ and $4.16 \AA$, respectively, in good agreement with the experimental values of $3.92 \AA$ and $4.09 \AA .{ }^{7}$ Having calculated the lattice constant of pure elements with reasonable accuracy, we calculated the lattice constant of the $\mathrm{Pt}-\mathrm{Ag}$ alloy systems at three intermediate compositions (calculated lattice constants in parentheses): $\operatorname{PtAg}_{3}(4.10 \AA)$, PtAg (4.06 $\AA$ ), and $\mathrm{Pt}_{3} \mathrm{Ag}(4.02 \AA)$. We based the Pt-Ag alloy structures on the fcc structure. Specifically, these systems were made to adopt the $\mathrm{L}_{2}$ crystal structure ( $\mathrm{AuCu}_{3}$ prototype) for $\mathrm{PtAg}_{3}$ and $\mathrm{Pt}_{3} \mathrm{Ag}$. The $\mathrm{L}_{0}$ crystal structure (AuCu prototype) was adopted for PtAg, assuming a cubic unit cell (and therefore only optimizing one lattice constant).

Surfaces were modeled using periodic boundary conditions and a $2 \times 2$ surface unit cell corresponding to a $1 / 4$ ML coverage of adsorbates on the (100) slabs considered in this study. The slabs were constructed with four metal layers; the bottom two were fixed while the top two were fully relaxed. The periodic images in the $z$-direction were separated by at least $14 \AA$ of vacuum. To capture small differences in energy to reproduce the observed experimental trend, we used a dense $k$-point mesh and a tight convergence criterion on the inter-atomic forces. Hence, the surface Brillouin zone was sampled using a $10 \times 10 \times 1$ Monkhorst-Pack $k$-point mesh, ${ }^{8}$ and the geometric optimization was performed until the Hellmann-Feynman forces on all atoms were less than $0.01 \mathrm{eV} / \AA$. Adsorbates were allowed to adsorb on one surface of the slab atop the relaxed layers, and the dipole correction to the electrostatic potential was included accordingly. ${ }^{9,10}$ 
The Gibbs free energies of gas-phase species and adsorbed intermediates were calculated as $\mathrm{G}=\mathrm{E}+\mathrm{ZPE}-\mathrm{TS}$, where $\mathrm{T}$ is the standard temperature of $298.15 \mathrm{~K}, \mathrm{E}$ is the electronic energy as calculated by DFT, ZPE is the zero-point energy correction to the electronic energy, and $\mathrm{S}$ is entropy. ZPE and $\mathrm{S}$ were estimated from the vibrational frequencies of adsorbates including translational, vibrational, and rotational modes. These were estimated by numerical differentiation of forces via a second-order finite difference approximation with a step size of $0.015 \AA$, and assuming harmonic oscillation. Our DFT-calculated Gibbs free energies were extrapolated to the fuel cell operating potential using the computational reversible hydrogen electrode of Nørskov et al. ${ }^{11}$ The electrochemical reference was chosen to be the reversible hydrogen electrode (RHE), at which protons and electrons are in equilibrium with hydrogen gas at a defined potential of $0 \mathrm{~V}$ at all $\mathrm{pH}$ and standard conditions of temperature $(298.15 \mathrm{~K})$ and pressure $(1 \mathrm{~atm})$. To correct for the applied electrochemical bias $(U)$, the free energy change of proton-electron transfer steps was calculated as $\Delta G=\Delta E+\Delta Z P E-T \Delta S+|e| U$. Hence, the Gibbs free energy of the Faradaic step $O^{*}+\left(H^{+}+e^{-}\right) \rightarrow O H^{*}$ (the asterisk denoting adsorbed species) becomes more endergonic by $|e| U$ with increasing potential. The activation energy barrier for electrochemical steps was assumed to be zero for exergonic steps and equal to the free energy of reaction for endergonic steps, in accordance with previous work. $^{12}$

The activation energy barriers for the non-Faradaic steps of $\mathrm{O}-\mathrm{O}$ bond scission in molecular oxygen $\left(\mathrm{O}_{2}\right)$ and peroxyl $(\mathrm{OOH})$ intermediates were calculated using the climbing-image nudged elastic band (CI-NEB) method. ${ }^{13}$ Seven intermediate images were interpolated between the start and final configurations, with a $0.05 \mathrm{eV} / \AA$ convergence criterion on the forces of each image. The transition state was verified by identifying a single imaginary vibrational mode, as estimated by the vibrational frequency calculations.

We finally recognize the limitations of the model adopted in this study. The electrochemical environment under which the experiments performed differ from our model in several aspects. In particular, our model ignores the explicit inclusion of solvation effects on the binding of any of our adsorbates. We include a uniform $0.1 \mathrm{eV}$ stabilization of hydroxyl $(\mathrm{OH})$ on all surfaces, following what was found previously for $\operatorname{Pt}(100) ;{ }^{14}$ no correction was made to the free energies of other species, according to what was found in that 
work. This value may differ among the different surfaces considered in this study; small variations in this value will not affect the conclusions of this work.

Surface segregation calculations. To most accurately represent the surface environment of the $\mathrm{Pt}-\mathrm{Ag}$ catalysts in this study, we considered a range of surface terminations for each intermediate $\mathrm{Pt}-\mathrm{Ag}$ composition. Specifically, we considered all unique permutations of $\mathrm{Pt}$ and $\mathrm{Ag}$ atoms in the top two layers for a given $\mathrm{Pt}-\mathrm{Ag}$ composition. For example, the $\mathrm{PtAg}$ surface (1:1 ratio of Pt:Ag) contains four Pt atoms and four Ag atoms in the top two layers. We therefore considered all permutations of these eight atoms, ranging from four $\mathrm{Pt}$ atoms in the top surface layer (with four Ag in the second layer) to four Ag atoms in the top layer (with four Pt in the second layer). We also considered the intermediate cases of one, two, and three Pt (Ag) atoms in the top surface layer, maintaining the overall 1:1 Pt:Ag ratio in the top two layers. The same process was repeated for the $\mathrm{PtAg}_{3}$ and $\mathrm{Pt}_{3} \mathrm{Ag}$ surfaces, noting that these surfaces had six or two atoms of each species in the top two layers, and therefore the number of permutations was reduced for these cases. These calculations were performed with no adsorbate (vacuum conditions) and in the presence of $0.25 \mathrm{ML} \mathrm{O}$ and $\mathrm{OH}$ (one adsorbed atom/molecule in the $2 \times 2$ unit cell), considering all unique adsorption sites for $\mathrm{O}$ and $\mathrm{OH}$ within the unit cell of each surface configuration. In the following, we summarize our findings for preferred (most negative total energy) surface compositions and configurations under vacuum, 0.25 ML O, and 0.25 ML OH.

We note that our model formulation permutes atoms in the top two layers, but requires an assumption about the composition of the third and fourth atomic layers at the bottom of the slab model. We assume that these layers follow the bulk crystal structures of the alloys; however, the identities of the layers depend on the assumed termination of the alloy. For example, the bottom two layers of the $\mathrm{Pt}_{3} \mathrm{Ag}$ surface can be arranged as $\mathrm{Pt}_{2} \mathrm{Ag}_{2} / \mathrm{Pt}_{4}$ or $\mathrm{Pt}_{4} /$ $\mathrm{Pt}_{2} \mathrm{Ag}_{2}$, and the bottom two layers of $\mathrm{PtAg}$ can be arranged as $\mathrm{Ag}_{4} / \mathrm{Pt}_{4}, \mathrm{Pt}_{4} / \mathrm{Ag}_{4}$, or $\mathrm{Pt}_{2} \mathrm{Ag}_{2} /$ $\mathrm{Pt}_{2} \mathrm{Ag}_{2}$ according to the assumed bulk crystal structures of these alloys. Accurate determination of the most stable composition of these layers in the real catalyst is not possible with the adopted surface model, since the exposure of the bottom face to vacuum creates a non-physical surface termination that biases the results toward Ag-rich bottom layer compositions (since Ag segregation to vacuum-terminated surfaces is preferred). We will 
show that the identity of the third and fourth layers does not typically impact the preferred structures of the first and second layers or adsorbates, and (more importantly) that the qualitative ORR trends are also not impacted by these bottom layers (next section). The top layer composition generally prefers to maximize the available Ag content under vacuum, while adsorbed $\mathrm{O}$ and $\mathrm{OH}$ prefer to bind to surface $\mathrm{Pt}$ sites and can therefore stabilize $\mathrm{Pt}$ on the surface.

The preferred compositions of the top two layers and corresponding adsorption configurations of $\mathrm{O}$ and $\mathrm{OH}$ for the $\mathrm{PtAg}_{3}$ alloy are shown in Tables $\mathrm{S} 2$ and $\mathrm{S} 3$ for the two respective arrangements of the third and fourth atomic layers. We observe that the preferred composition of the top layer under vacuum contains the maximum amount of $\mathrm{Ag}$, in accordance with its tendency to segregate to the (100) surface relative to $\mathrm{Pt}^{15}$ This preference remains the same in the presence of $0.25 \mathrm{ML} \mathrm{O}$ or $\mathrm{OH}$; while the surface Pt atoms are stabilized slightly by the presence of $\mathrm{O} / \mathrm{OH}$ compared to the vacuum case, the stabilization is insufficient to drive Pt to the surface. We also observe that the two different configurations for the bottom two layers had no effect on the structure of the top two layers or the adsorption configurations of $\mathrm{O}$ and $\mathrm{OH}$. In addition to this qualitative agreement, we observe that the largest difference in energies for corresponding entries in Tables S2 and S3 brought about by varying the bottom layers' configuration is $0.13 \mathrm{eV}$ (for $\mathrm{O}$ adsorption on the $\mathrm{Pt}_{2} \mathrm{Ag}_{2} / \mathrm{Ag}_{4}$ top layer configuration). These data indicate that the structure of the bottom two layers may play a relatively insignificant role in determining the overall surface energetics, as we show in the next section when evaluating ORR energetics.

Table S4 shows the most stable compositions of the top two layers and the corresponding adsorption configurations of $\mathrm{O}$ and $\mathrm{OH}$ for the $\mathrm{PtAg}$ alloy with $\mathrm{Pt}_{2} \mathrm{Ag}_{2}$ compositions for the third and fourth layers. Under vacuum, Pt again prefers the subsurface layer, yielding a pure Ag topmost layer as the most stable structure. This, however, is not the case in the presence of $0.25 \mathrm{ML} \mathrm{O}$ or $\mathrm{OH}$ : adsorbate-induced segregation leads to the $\mathrm{Pt}_{2} \mathrm{Ag}_{2}$ surface being most stable.

Table S5 shows the most stable compositions of the top two layers and corresponding adsorption configurations of $\mathrm{O}$ and $\mathrm{OH}$ for the PtAg alloy when the third layer is pure $\mathrm{Pt}$ and the bottom layer pure Ag. The preferred surface composition under vacuum is again purely 
Ag-terminated; importantly, this pure Ag termination is still preferred in the presence of $\mathrm{OH}$, as $\mathrm{OH}$ adsorption does not provide sufficient stabilization of surface $\mathrm{Pt}$ when the third and fourth layers are arranged in this fashion. This will be an important special case to consider, as we discuss in the next section. As in the previous case in Table S4, atomic oxygen stabilizes two Pt atoms in the surface layer of the most preferred configuration.

Table S6 shows the most stable compositions of the top two surface layers and corresponding adsorption configurations of $\mathrm{O}$ and $\mathrm{OH}$ for the PtAg alloy when the third layer is pure $\mathrm{Ag}$ and the bottom layer pure Pt. A pure Ag topmost layer is still the most stable structure in vacuum. As in the case of the $\mathrm{Pt}_{2} \mathrm{Ag}_{2}$ third and fourth layers (Table $\mathrm{S} 4$ ), adsorbate-induced segregation stabilizes two surface $\mathrm{Pt}$ atoms, and the preferred compositions in the presence of $0.25 \mathrm{ML} \mathrm{O}$ or $\mathrm{OH}$ is a $\mathrm{Pt}_{2} \mathrm{Ag}_{2}$ surface.

Considering all three PtAg studies, the effect of the configurations of the bottom two layers was relatively small in determining the relative stabilities of the top two layers. Under vacuum, Ag always prefers the surface layer regardless of the structure of the bottom two layers. The trend in $\mathrm{O}$ was also similar among the different bottom-layer structures, where $\mathrm{O}$ always prefers to pull two $\mathrm{Pt}$ atoms to the surface, to which it adsorbs near the $\mathrm{Pt}-\mathrm{Pt}$ bridge site. The same trend is also obtained for $\mathrm{OH}$, except for the system with a pure $\mathrm{Ag}$ bottommost layer (Table S5), where $\mathrm{OH}$ prefers to bind to an all Ag topmost layer. This could be attributed to having two adjacent layers of pure Pt in this system (the second and third layers), hence the difficulty of breaking this $\mathrm{Pt}-\mathrm{Pt}$ cohesion with $\mathrm{OH}$, which forms weaker bonds with $\mathrm{Pt}$ than atomic $\mathrm{O}$.

The preferred compositions of the top two layers and corresponding adsorption configurations of $\mathrm{O}$ and $\mathrm{OH}$ for the $\mathrm{Pt}_{3} \mathrm{Ag}$ alloy are shown in Tables $\mathrm{S} 7$ and $\mathrm{S} 8$ for the two respective arrangements of the third and fourth atomic layers. As in the case of the $\mathrm{PtAg}_{3}$ system, we observe the preferred surface composition remains the same under vacuum, $\mathrm{O}$, and $\mathrm{OH}$. In this case, the system again prefers to maximize its Ag surface content with both available $\mathrm{Ag}$ atoms located in the top layer; $\mathrm{O}$ and $\mathrm{OH}$ adsorb to adjacent $\mathrm{Pt}$ atoms and do not drive any additional Pt to the surface. As with $\mathrm{PtAg}_{3}$, the third and fourth atomic layers had no impact on the identity of the preferred first/second layer compositions or $\mathrm{O} / \mathrm{OH}$ adsorption structure. The magnitudes of the segregation energies were more affected by the bottom layer 
compositions (with differences up to $0.3 \mathrm{eV}$ with changing bottom layer composition), though this did not have any impact upon our final conclusions or any qualitative trends.

Calculations of ORR mechanism. We performed calculations of the detailed ORR mechanism on the lowest energy surfaces described in the previous section. Specifically, we performed calculations on a Ag-terminated surface for $\mathrm{PtAg}_{3}, \mathrm{at}_{2} \mathrm{Ag}_{2}$-terminated surface for $\mathrm{Pt}_{3} \mathrm{Ag}$, and a $\mathrm{Pt}_{2} \mathrm{Ag}_{2^{-}}$or $\mathrm{Ag}$ - terminated surface for PtAg. We noted above that our methodology for calculating the preferred compositions of the bimetallic surfaces required an assumption about the composition of the third and fourth metal layers. To be rigorous, we also calculated the detailed ORR mechanism on the most stable surfaces (with respect to the best arrangement of the top two surface layers) for each of the two or three possible compositions of the third and fourth layers. For most cases ( $\mathrm{PtAg}_{3}$ and $\mathrm{Pt}_{3} \mathrm{Ag}$, specifically), the composition of the top two surface layers was the same in vacuum or in the presence of $O$ or $\mathrm{OH}$. For the PtAg case, we performed calculations on the most stable surfaces in the presence of adsorbed $\mathrm{OH}$, since we anticipate this to be the majority surface species. For third layer compositions of pure $\mathrm{Ag}$ or $\mathrm{Pt}_{2} \mathrm{Ag}_{2}$, these preferred top layer compositions of $\mathrm{Pt}_{2} \mathrm{Ag}_{2}$ are also the most stable termination in the presence of atomic $\mathrm{O}$. As noted above, the most stable termination in the presence of $\mathrm{OH}$ in the presence of $0.25 \mathrm{ML} \mathrm{OH}$ is purely Ag-terminated when the third layer has only Pt atoms; we therefore performed calculations of the detailed ORR mechanism on this surface to determine its significance as a potential ORR catalyst surface.

We provide the calculated free energy diagrams in Table S9; the numerical data for all surfaces and adsorbed states are given in Table S10. For reference, selected binding energies and activation energy barriers are provided in Table S11. While there are small differences in the calculated ORR energetics when changing the identity of the third and fourth layers (generally less than $0.1 \mathrm{eV}$ ), these differences do not affect the overall trend observed when comparing energetics across all compositions as in Figure 4B of the main text. The primary exception is the case of PtAg, which as mentioned has a thermodynamically preferred Ag-only termination when the third layer is composed of only Pt. In this case, the ORR mechanism would proceed through the $\mathrm{OOH}$ intermediate (as in the case of the $\mathrm{Ag}$-terminated $\mathrm{PtAg}_{3}$ and $\mathrm{Ag}$ surfaces). However, this $\mathrm{OOH}$ intermediate is less stable than 
that in the other cases, likely due to the combination of strain and ligand effects (as discussed in the main text for $\mathrm{O}_{2}$ transition state stabilization) causing destabilization of $\mathrm{OOH}$ and the $\mathrm{OOH}$ transition state. We therefore predict that this specific Ag-terminated surface would be less active than the $\mathrm{Ag}$ and $\mathrm{PtAg}_{3}$ surfaces, and therefore is not representative of the true PtAg surface due to its observed high experimental activity relative to $\mathrm{Ag}$ and $\mathrm{PtAg}_{3}$. We observe that for the remaining compositions, surfaces with Pt-rich third layer compositions uniformly bind intermediates more strongly than their counterparts with Ag-rich third layer compositions by $0.0-0.1 \mathrm{eV}$. Although we conclude that the specific composition of the third and fourth layers does not impact the qualitative conclusions reached in this study, it does suggest that the nature of the third layer is important for determining finer details of the oxygen reduction reaction.

As discussed previously, it is not physically meaningful to compare the total energies of surfaces on the basis of differences in their third- and fourth-layer compositions due to the artificial surface termination created in our model. We constructed Figure 4B of the main text, which compares the lowest energy reaction pathway on each alloy composition, using the surfaces with mixed third-layer compositions. We anticipate that $\mathrm{Pt}$ and $\mathrm{Ag}$ should be reasonably well-mixed as a result of the galvanic replacement reaction and subsequent diffusion/exchange of atoms during dealloying. As discussed previously, this choice of surface does not impact the qualitative nature of the conclusion reached in this study (except for the previously discussed Ag-terminated PtAg alloy), which is that the stability of the transition state for $\mathrm{O}-\mathrm{O}$ bond breaking determines the experimentally-observed activity.

\section{References}

1. Ruditskiy A, Xia Y. Toward the synthesis of sub-15 nm Ag nanocubes with sharp corners and edges: the roles of heterogeneous nucleation and surface capping. Journal of the American Chemical Society 2016, 138, 3161-3167.

2. Kresse G, Furthmüller J. Efficient iterative schemes for ab initio total-energy calculations using a plane-wave basis set. Physical Review B 1996, 54,11169-11186. 
3. Kresse G, Furthmüller J. Efficiency of ab-initio total energy calculations for metals and semiconductors using a plane-wave basis set. Computational Materials Science 1996, 6, $15-50$.

4. Blöchl PE. Projector augmented-wave method. Physical Review B 1994, 50, 17953-17979.

5. Kresse G, Joubert D. From ultrasoft pseudopotentials to the projector augmented-wave method. Physical Review B 1999, 59, 1758-1775.

6. Perdew JP, Wang Y. Accurate and simple analytic representation of the electron-gas correlation energy. Physical Review B 1992, 45, 13244-13249.

7. CRC handbook of chemistry and physics, 95 ed.; CRC Press, New York, 2014-2015.

8. Monkhorst HJ, Pack JD. Special points for brillouin-zone integrations. Physical Review B 1976, 13, 5188-5192.

9. Neugebauer J, Scheffler M. Adsorbate-substrate and adsorbate-adsorbate interactions of $\mathrm{Na}$ and K adlayers on Al(111). Physical Review B 1992, 46, 16067-16080.

10. Bengtsson L. Dipole correction for surface supercell calculations. Physical Review B 1999, 59, 12301-12304.

11. Nørskov JK, Rossmeisl J, Logadottir A, Lindqvist L, Kitchin JR, Bligaard T, Jónsson H. Origin of the overpotential for oxygen reduction at a fuel-cell cathode. Journal of Physical Chemistry B 2004, 108, 17886-17892.

12. Koper MTM. Thermodynamic theory of multi-electron transfer reactions: implications for electrocatalysis. Journal of Electroanalytical Chemistry 2011, 660, 254-260.

13. Henkelman G, Uberuaga BP, Jonsson H. A climbing image nudged elastic band method for finding saddle points and minimum energy paths. Journal of Chemical Physics 2000, 113, 9901-9904.

14. Greeley J, Rossmeisl J, Hellman A, Nørskov JK. Theoretical Trends in Particle Size Effect for the Oxygen Reduction Reaction. Z. Phys. Chem. 2007, 221, 1209-1220.

15. Nilekar AU, Ruban AV, Mavrikakis M. Surface segregation energies in low-index open surfaces of bimetallic transition metal alloys. Surface Science 2009, 603, 91-96. 

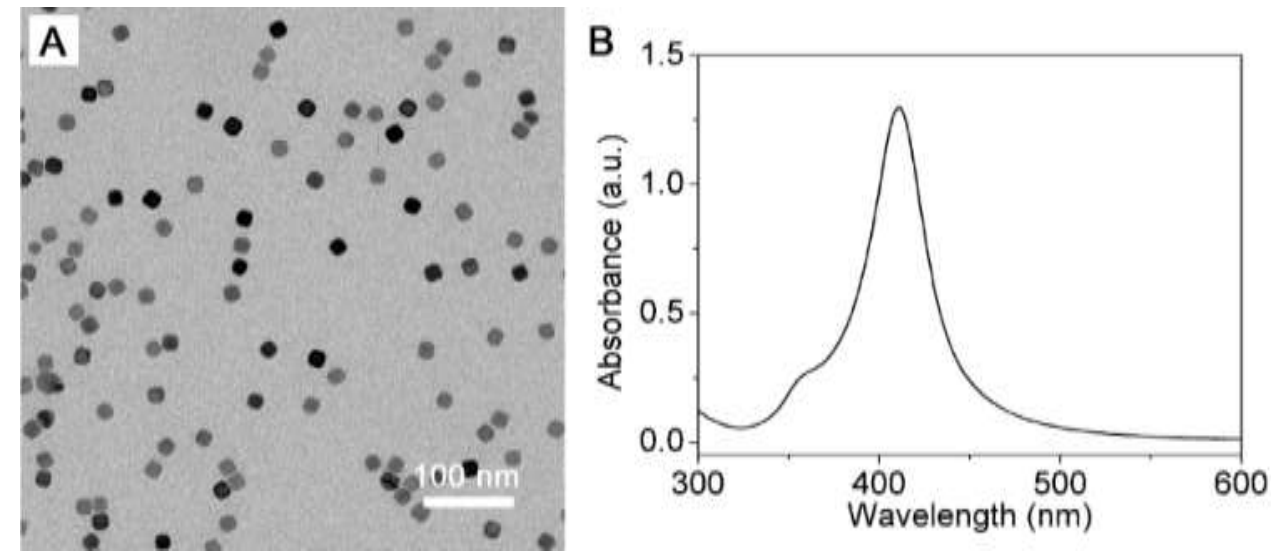

Figure S1. (A) TEM image and (B) UV-vis spectrum of the Ag nanocubes used as templates for the synthesis of $\mathrm{Pt}-\mathrm{Ag}$ nanocages. 


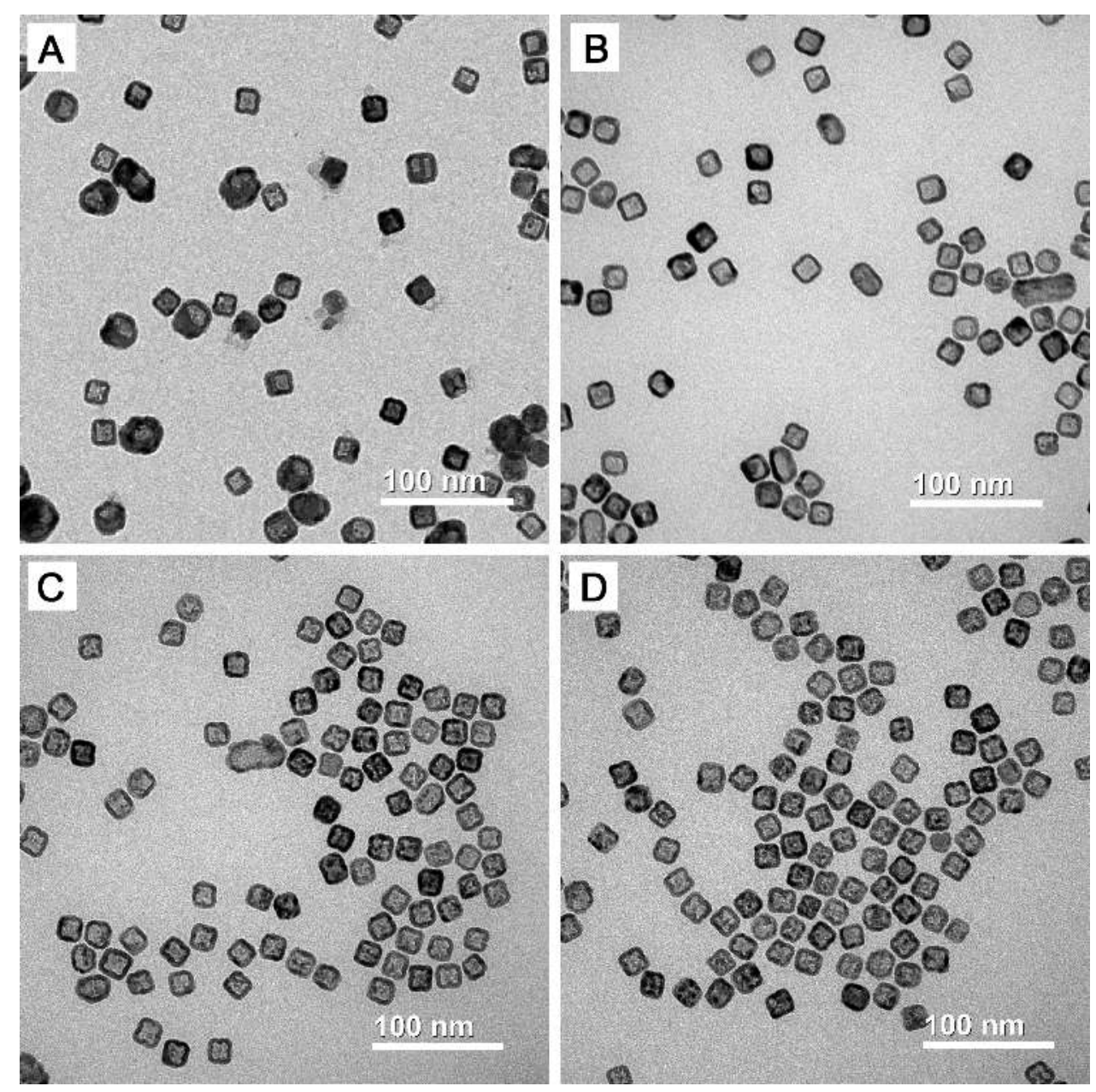

Figure S2. TEM images of $\mathrm{Pt}-\mathrm{Ag}$ nanocages synthesized at $40{ }^{\circ} \mathrm{C}$ with different amounts of $\mathrm{K}_{2} \mathrm{PtCl}_{4}$ : (A) 0.1, (B) 0.2, (C) 0.8, and (D) $1.2 \mathrm{~mL}$. 


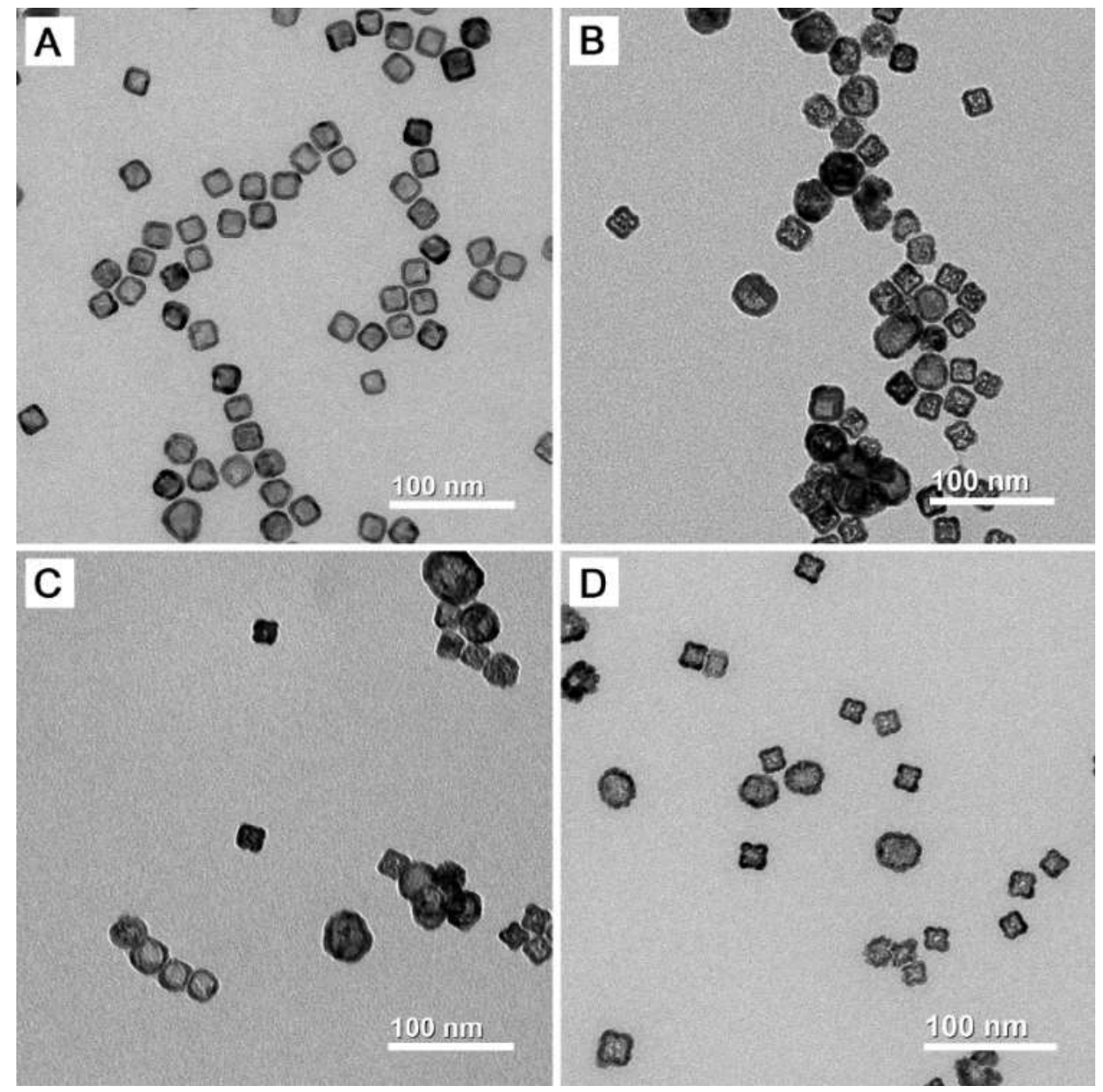

Figure S3. TEM images of Pt-Ag nanocages synthesized with $0.4 \mathrm{~mL}$ of $\mathrm{K}_{2} \mathrm{PtCl}_{4}$ at different temperature: (A) 40, (B) 60, (C) 80, and (D) $100{ }^{\circ} \mathrm{C}$. 


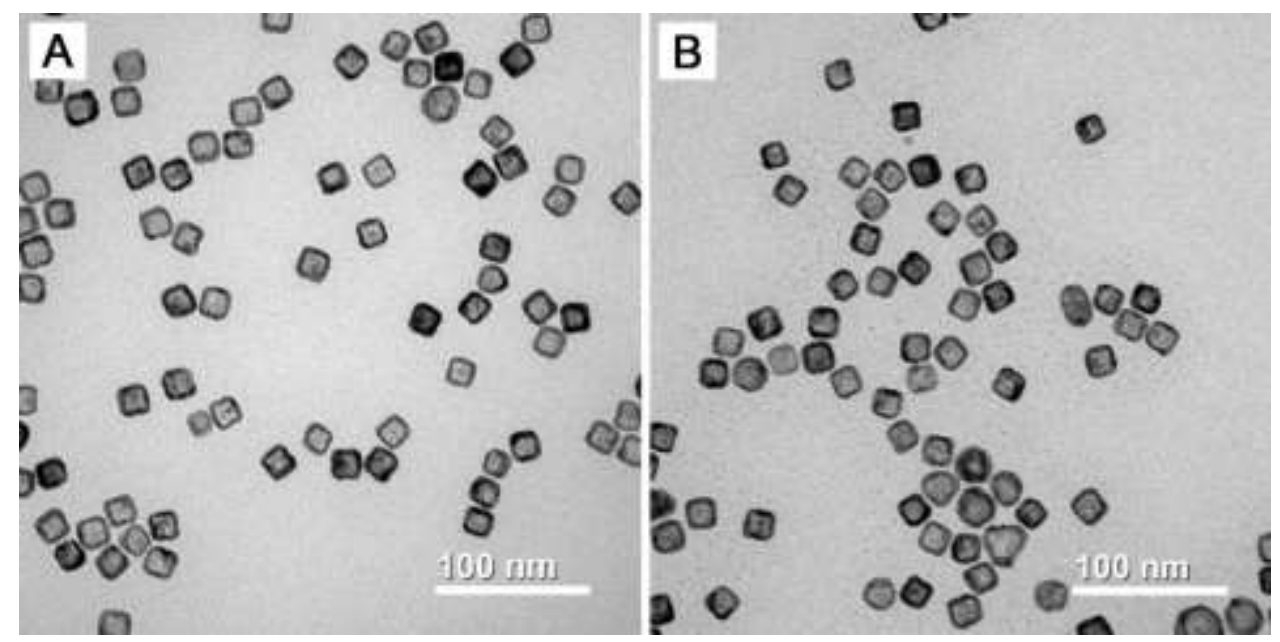

Figure S4. TEM images of $\mathrm{Pt}-\mathrm{Ag}$ nanocages with $0.4 \mathrm{~mL}$ of $\mathrm{K}_{2} \mathrm{PtCl}_{4}$ at $40{ }^{\circ} \mathrm{C}$ using different injection methods: (A) dropwise and (B) one shot, respectively. When the Pt precursor was injected in one shot, the sample contained some tiny nanoparticles with a size of about $2 \mathrm{~nm}$, which were formed through self-nucleation. 


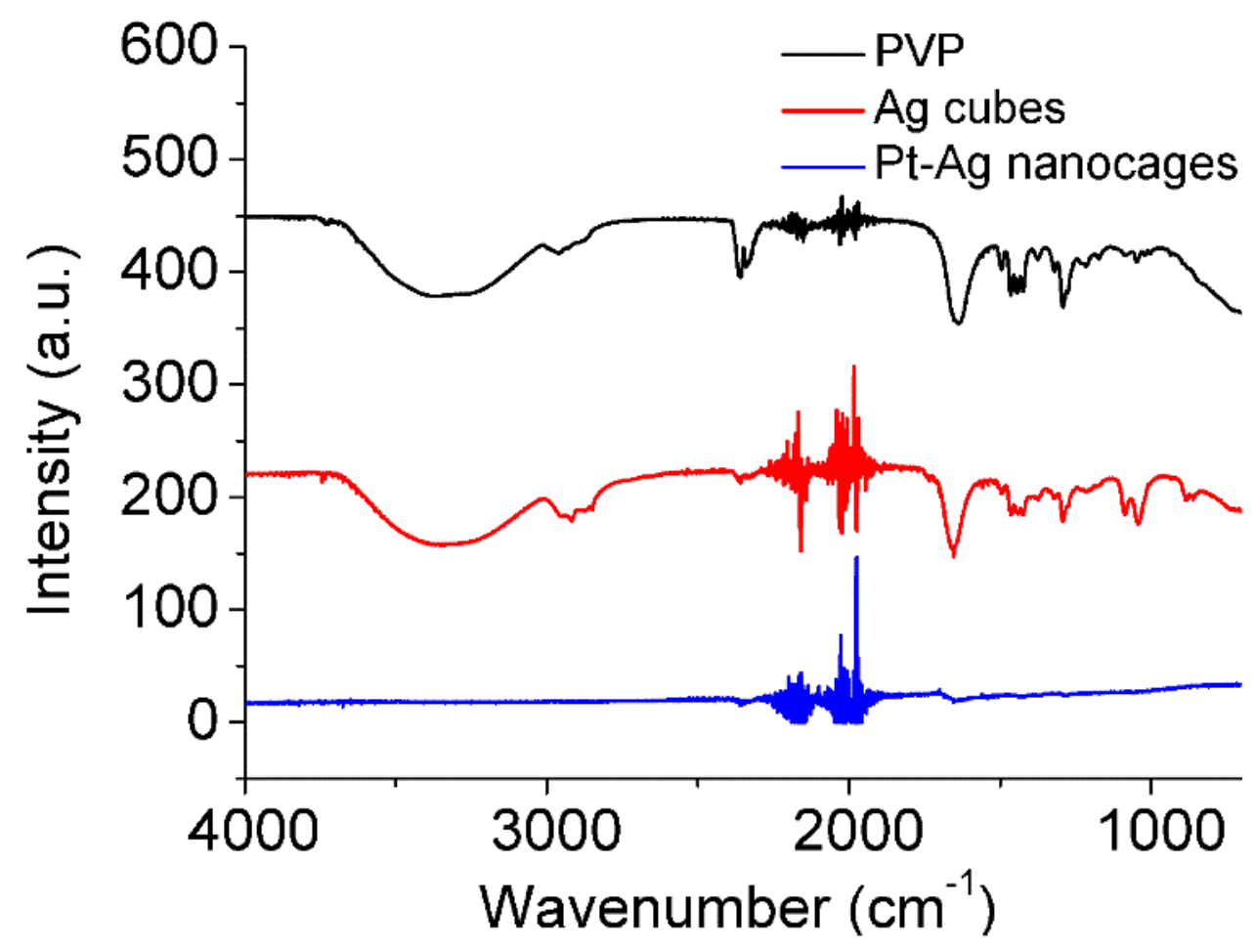

Figure S5. FTIR spectra of PVP, Ag nanocubes, and Pt-Ag nanocages. The absorption band at $1630 \mathrm{~cm}^{-1}$ can be assigned to the $\mathrm{C}=\mathrm{O}$ bond in PVP. 

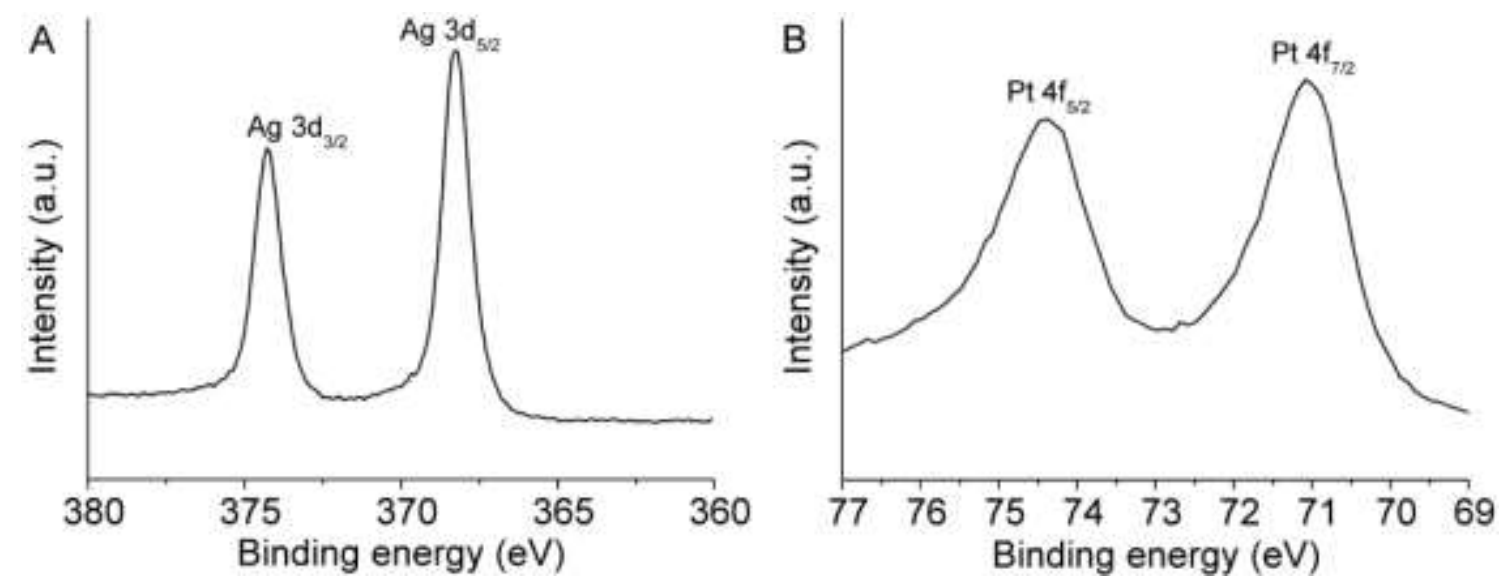

Figure S6. Typical XPS spectra of (A) $\mathrm{Ag}$ and (B) $\mathrm{Pt}$ in the $\mathrm{Pt}-\mathrm{Ag}$ nanocages shown in Figure 2. Both the $\mathrm{Ag}$ and $\mathrm{Pt}$ in the $\mathrm{Pt}-\mathrm{Ag}$ nanocages are zero-valent, suggesting that there is little oxygen species $(\mathrm{O}$ or $\mathrm{OH})$ on the surface of the $\mathrm{Pt}-\mathrm{Ag}$ nanocages. 
Table S1. ICP-MS data used for the determining the compositions of the Pt-Ag nanocages.

\begin{tabular}{|c|c|c|}
\hline Sample & Composition & $\begin{array}{c}\text { Wall thickness } \\
\text { (nm) }\end{array}$ \\
\hline $\mathrm{Pt}-\mathrm{Ag}$ nanocages & $\mathrm{Pt}_{19} \mathrm{Ag}_{81}$ & $\sim 3.1$ \\
\hline $\begin{array}{l}\mathrm{Pt}-\mathrm{Ag} / \mathrm{C} \text { nanocages } \\
\text { after } 5000 \text { cycles ADT }\end{array}$ & $\mathrm{Pt}_{46} \mathrm{Ag}_{54}$ & \\
\hline $\begin{array}{l}\mathrm{Pt}-\mathrm{Ag} / \mathrm{C} \text { nanocages } \\
\text { after } 10000 \text { cycles ADT }\end{array}$ & $\mathrm{Pt}_{56} \mathrm{Ag}_{44}$ & \\
\hline $\begin{array}{l}\mathrm{Pt}-\mathrm{Ag} / \mathrm{C} \text { nanocages } \\
\text { after } 20000 \text { cycles ADT }\end{array}$ & $\mathrm{Pt}_{65} \mathrm{Ag}_{35}$ & \\
\hline $\begin{array}{l}\mathrm{Pt}-\mathrm{Ag} / \mathrm{C} \text { nanocages } \\
\text { after } 30000 \text { cycles ADT }\end{array}$ & $\mathrm{Pt}_{79} \mathrm{Ag}_{21}$ & \\
\hline
\end{tabular}

ADT: Accelerated Durability Test 
Table S2. Minimum-energy (100) surface configurations for the $\mathrm{PtAg}_{3}$ alloy with a pure $\mathrm{Ag}$ third layer and $\mathrm{Pt}_{2} \mathrm{Ag}_{2}$ bottom layer. The insets show the top view of the most stable structures calculated under vacuum, $0.25 \mathrm{ML}$ of $\mathrm{O}$, and $0.25 \mathrm{ML}$ of $\mathrm{OH}$. The relative energies of different surfaces (within each column) are given in $\mathrm{eV}$ below each inset. A more positive relative energy indicates a less stable structure/configuration. Atom colors: Ag (yellow), $\mathrm{Pt}$ (grey), O(red), $\mathrm{H}$ (white).

\begin{tabular}{|c|c|c|c|}
\hline $\begin{array}{c}1^{\text {st }} / 2^{\text {nd }} \text { Layer } \\
\text { Compositions }\end{array}$ & Vacuum & $0.25 \mathrm{MLO}$ & $0.25 \mathrm{ML} \mathrm{OH}$ \\
\hline $\begin{array}{c}1^{\text {st }} / 2^{\text {nd }} \text { layers: } \\
\mathrm{Ag}_{4} / \mathrm{Pt}_{2} \mathrm{Ag}_{2}\end{array}$ & & & \\
\hline $\begin{array}{c}1^{\text {st }} / 2^{\text {nd }} \text { layers: } \\
\mathrm{Pt}_{1} \mathrm{Ag}_{3} / \mathrm{Pt}_{1} \mathrm{Ag}_{3}\end{array}$ & & & \\
\hline & 0.33 & 0.01 & 0.31 \\
\hline \multirow[t]{2}{*}{$\begin{array}{c}1^{\text {st }} / 2^{\text {nd }} \text { layers: } \\
\mathrm{Pt}_{2} \mathrm{Ag}_{2} / \mathrm{Ag}_{4}\end{array}$} & & & \\
\hline & 0.77 & 0.23 & 0.62 \\
\hline
\end{tabular}


Table S3. Minimum-energy (100) surface configurations for the $\mathrm{PtAg}_{3}$ alloy with a $\mathrm{Pt}_{2} \mathrm{Ag}_{2}$ third layer and pure Ag bottom layer. The insets show the top view of the most stable structures calculated under vacuum, $0.25 \mathrm{ML}$ of $\mathrm{O}$, and $0.25 \mathrm{ML}$ of $\mathrm{OH}$. The relative energies of different surfaces (within each column) are given in $\mathrm{eV}$ below each inset. A more positive relative energy indicates a less stable structure/configuration. Atom colors: Ag (yellow), $\mathrm{Pt}$ (grey), O(red), H(white).

\begin{tabular}{|c|c|c|c|}
\hline $\begin{array}{c}1^{\text {st }} / 2^{\text {nd }} \text { Layer } \\
\text { Compositions }\end{array}$ & Vacuum & $0.25 \mathrm{ML} \mathrm{O}$ & $0.25 \mathrm{ML} \mathrm{OH}$ \\
\hline \multicolumn{4}{|l|}{$\begin{array}{l}\text { 1st/2nd layers: } \\
\mathrm{Ag}_{4} / \mathrm{Pt}_{2} \mathrm{Ag}_{2}\end{array}$} \\
\hline & 0.00 & 0.00 & 0.00 \\
\hline \multicolumn{4}{|l|}{$\begin{array}{l}\text { 1st/2nd layers: } \\
\mathrm{Pt}_{1} \mathrm{Ag}_{3} / \mathrm{Pt}_{1} \mathrm{Ag}_{3}\end{array}$} \\
\hline & 0.42 & 0.12 & 0.42 \\
\hline \multicolumn{4}{|l|}{$\begin{array}{l}\text { 1st/2nd layers: } \\
\mathrm{Pt}_{2} \mathrm{Ag}_{2} / \mathrm{Ag}_{4}\end{array}$} \\
\hline & 0.88 & 0.36 & 0.68 \\
\hline
\end{tabular}


Table S4. Minimum-energy (100) surface configurations for the PtAg alloy with a $\mathrm{Pt}_{2} \mathrm{Ag}_{2}$ third layer and $\mathrm{Pt}_{2} \mathrm{Ag}_{2}$ bottom layer. The insets show the top view of the most stable structures calculated under vacuum, $0.25 \mathrm{ML}$ of $\mathrm{O}$, and $0.25 \mathrm{ML}$ of $\mathrm{OH}$. The relative energies of different surfaces (within each column) are given in $\mathrm{eV}$ below each inset. A more positive relative energy indicates a less stable structure/configuration. Atom colors: Ag (yellow), $\mathrm{Pt}$ (grey), O(red), H(white).

\begin{tabular}{|c|c|c|c|c|}
\hline $1^{\text {st }} / 2^{\text {nd }}$ Layer \\
Compositions
\end{tabular}


Table S5. Minimum-energy (100) surface configurations for the PtAg alloy with a pure Pt third layer and pure Ag bottom layer. The insets show the top view of the most stable structures calculated under vacuum, $0.25 \mathrm{ML}$ of $\mathrm{O}$, and $0.25 \mathrm{ML}$ of $\mathrm{OH}$. The relative energies of different surfaces (within each column) are given in $\mathrm{eV}$ below each inset. A more positive relative energy indicates a less stable structure/configuration. Atom colors: Ag (yellow), $\mathrm{Pt}$ (grey), O(red), $\mathrm{H}$ (white).

\begin{tabular}{|c|c|c|c|}
\hline $\begin{array}{c}1^{\text {st }} / 2^{\text {nd }} \text { Layer } \\
\text { Compositions }\end{array}$ & Vacuum & $0.25 \mathrm{MLO}$ & $0.25 \mathrm{ML} \mathrm{OH}$ \\
\hline \multicolumn{4}{|l|}{$\mathrm{Ag}_{4} / \mathrm{Pt}_{4}$} \\
\hline \multicolumn{4}{|l|}{$\mathrm{Pt}_{1} \mathrm{Ag}_{3} / \mathrm{Pt}_{3} \mathrm{Ag}_{1}$} \\
\hline \multicolumn{4}{|l|}{$\mathrm{Pt}_{2} \mathrm{Ag}_{2} / \mathrm{Pt}_{2} \mathrm{Ag}_{2}$} \\
\hline \multicolumn{4}{|l|}{$\mathrm{Pt}_{3} \mathrm{Ag}_{1} / \mathrm{Pt}_{1} \mathrm{Ag}_{3}$} \\
\hline \multicolumn{4}{|l|}{$\mathrm{Pt}_{4} / \mathrm{Ag}_{4}$} \\
\hline & 2.41 & 1.26 & \\
\hline
\end{tabular}


Table S6. Minimum-energy (100) surface configurations for the PtAg alloy with a pure Ag third layer and pure Pt bottom layer. The insets show the top view of the most stable structures calculated under vacuum, $0.25 \mathrm{ML}$ of $\mathrm{O}$, and $0.25 \mathrm{ML}$ of $\mathrm{OH}$. The relative energies of different surfaces (within each column) are given in $\mathrm{eV}$ below each inset. A more positive relative energy indicates a less stable structure/configuration. Atom colors: Ag (yellow), $\mathrm{Pt}$ (grey), O(red), H(white).

\begin{tabular}{|c|c|c|c|c|}
\hline $1^{\text {st }} / 2^{\text {nd }}$ Layer \\
Compositions
\end{tabular}


Table S7. Minimum-energy (100) surface configurations for the $\mathrm{Pt}_{3} \mathrm{Ag}$ alloy with a pure $\mathrm{Pt}$ third layer and $\mathrm{Pt}_{2} \mathrm{Ag}_{2}$ bottom layer. The insets show the top view of the most stable structures calculated under vacuum, $0.25 \mathrm{ML}$ of $\mathrm{O}$, and $0.25 \mathrm{ML}$ of $\mathrm{OH}$. The relative energies of different surfaces (within each column) are given in $\mathrm{eV}$ below each inset. A more positive relative energy indicates a less stable structure/configuration. Atom colors: Ag (yellow), $\mathrm{Pt}$ (grey), O(red), H(white).

\begin{tabular}{|l|l|l|l|}
\hline $1^{\text {st }} / 2^{\text {nd }}$ Layer & $0.25 \mathrm{MLO}$ & $0.25 \mathrm{MLOH}$ \\
Compositions & Vacuum & \\
\hline $\mathrm{Pt}_{2} \mathrm{Ag}_{2} / \mathrm{Pt}_{4}$ & & \\
\hline
\end{tabular}


Table S8. Minimum-energy (100) surface configurations for the $\mathrm{Pt}_{3} \mathrm{Ag}$ alloy with a $\mathrm{Pt}_{2} \mathrm{Ag}_{2}$ third layer and pure Pt bottom layer. The insets show the top view of the most stable structures calculated under vacuum, $0.25 \mathrm{ML}$ of $\mathrm{O}$, and $0.25 \mathrm{ML}$ of $\mathrm{OH}$. The relative energies of different surfaces (within each column) are given in $\mathrm{eV}$ below each inset. A more positive relative energy indicates a less stable structure/configuration. Atom colors: Ag (yellow), Pt(grey), O(red), H(white).

\begin{tabular}{|l|l|l|l|}
\hline $\begin{array}{c}1^{\text {st }} / 2^{\text {nd }} \text { Layer } \\
\text { Compositions }\end{array}$ & $0.25 \mathrm{MLO}$ & $0.25 \mathrm{MLOH}$ \\
\hline $\mathrm{Pt}_{2} \mathrm{Ag}_{2} / \mathrm{Pt}_{4}$ & Vacuum & \\
\hline $\mathrm{Pt}_{3} \mathrm{Ag}_{1} / \mathrm{Pt}_{3} \mathrm{Ag}_{1}$ & & & \\
\hline
\end{tabular}


Table S9. Free energy diagrams for the oxygen reduction reaction on (100) surfaces considered in this study. For systems with multiple possible third layer compositions, the PES is shown for all considered compositions (see Table S10 for additional details).

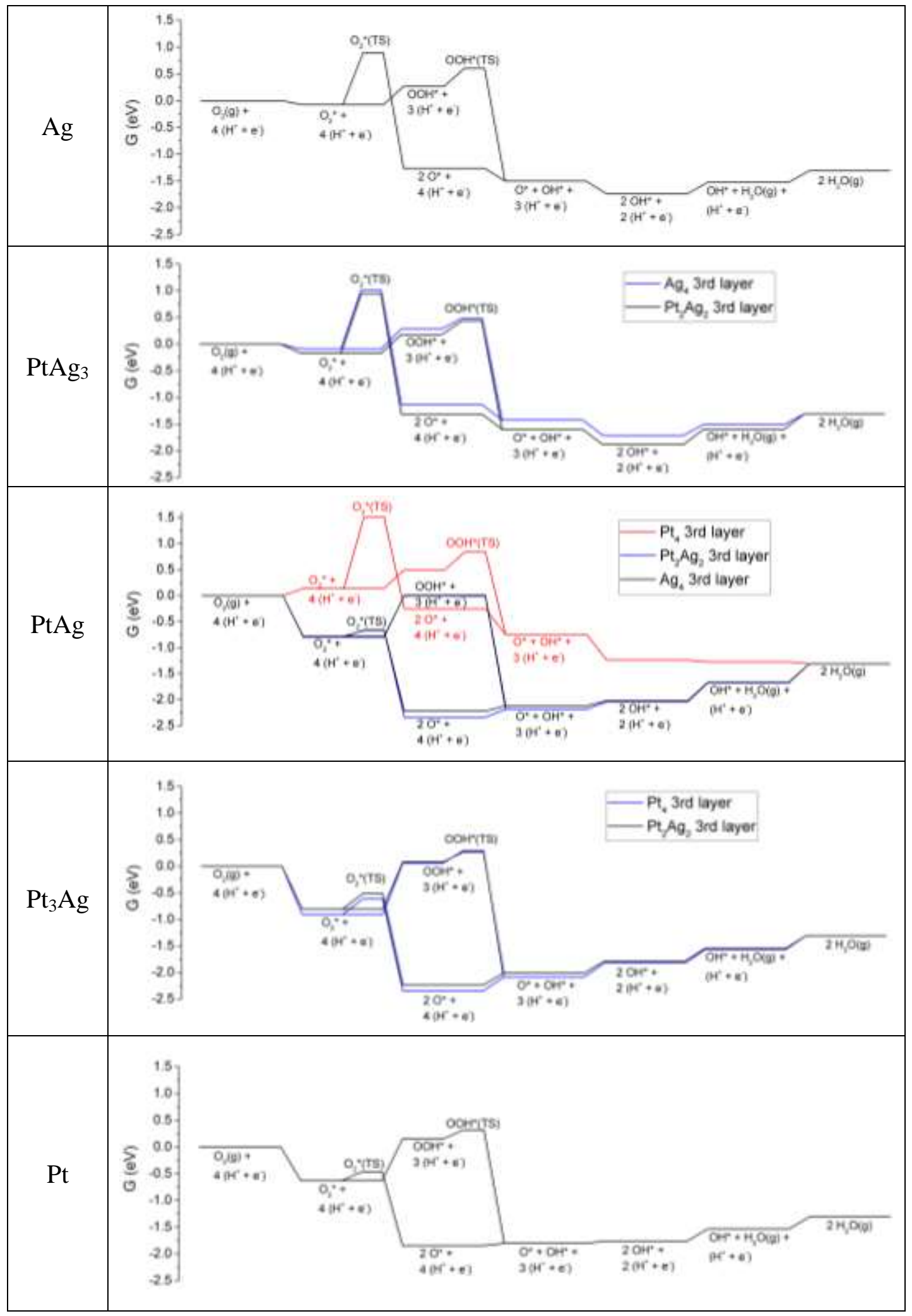


Table S10. Free energies of ORR intermediates relative to gas-phase $\mathrm{O}_{2}$ and $\mathrm{H}_{2}$ at $0.90 \mathrm{~V}_{\text {RHE}}$. The free energy of the final state $\left(2 \mathrm{H}_{2} \mathrm{O}(\mathrm{g})\right)$ was calculated to be $-1.31 \mathrm{eV}$. All numerical values are given in $\mathrm{eV}$.

\begin{tabular}{|c|c|c|c|c|c|c|c|c|c|}
\hline \multirow{2}{*}{$\begin{array}{l}\text { Surface } \\
3^{\text {rd }} / 4^{\text {th }} \text { Layer } \\
\text { Composition }\end{array}$} & \multirow{2}{*}{$\begin{array}{c}\operatorname{Ag}(100) \\
\operatorname{Ag}\end{array}$} & \multicolumn{2}{|c|}{$\mathrm{PtAg}_{3}(100)$} & \multicolumn{3}{|c|}{ PtAg(100) } & \multicolumn{2}{|c|}{$\mathrm{Pt}_{3} \mathrm{Ag}(100)$} & \multirow{2}{*}{$\begin{array}{c}\mathrm{Pt}(100) \\
\mathrm{Pt}\end{array}$} \\
\hline & & $\begin{array}{c}\mathrm{Ag}_{4} / \\
\mathrm{Pt}_{2} \mathrm{Ag}_{2}\end{array}$ & $\begin{array}{c}\mathrm{Pt}_{2} \mathrm{Ag}_{2} / \\
\mathrm{Ag}_{4}\end{array}$ & $\begin{array}{c}\mathrm{Ag}_{4} / \\
\mathrm{Pt}_{4}\end{array}$ & $\begin{array}{l}\mathrm{Pt}_{2} \mathrm{Ag}_{2} / \\
\mathrm{Pt}_{2} \mathrm{Ag}_{2}\end{array}$ & $\begin{array}{l}\mathrm{Pt}_{4} / \\
\mathrm{Ag}_{4}\end{array}$ & $\begin{array}{c}\mathrm{Pt}_{2} \mathrm{Ag}_{2} / \\
\mathrm{Pt}_{4}\end{array}$ & $\begin{array}{c}\mathrm{Pt}_{4} / \\
\mathrm{Pt}_{2} \mathrm{Ag}_{2}\end{array}$ & \\
\hline $\begin{array}{l}\text { Preferred } \\
1^{\text {st }} / 2^{\text {nd }} \text { Layer } \\
\text { Composition }\end{array}$ & $\mathrm{Ag}$ & $\begin{array}{c}\mathrm{Ag}_{4} / \\
\mathrm{Pt}_{2} \mathrm{Ag}_{2}\end{array}$ & $\begin{array}{c}\mathrm{Ag}_{4} / \\
\mathrm{Pt}_{2} \mathrm{Ag}_{2}\end{array}$ & $\begin{array}{l}\mathrm{Pt}_{2} \mathrm{Ag}_{2} / \\
\mathrm{Pt}_{2} \mathrm{Ag}_{2}\end{array}$ & $\begin{array}{l}\mathrm{Pt}_{2} \mathrm{Ag}_{2} / \\
\mathrm{Pt}_{2} \mathrm{Ag}_{2}\end{array}$ & $\begin{array}{c}\mathrm{Ag}_{4} / \\
\mathrm{Pt}_{4}\end{array}$ & $\begin{array}{c}\mathrm{Pt}_{2} \mathrm{Ag}_{2} / \\
\mathrm{Pt}_{4}\end{array}$ & $\begin{array}{c}\mathrm{Pt}_{2} \mathrm{Ag}_{2} / \\
\mathrm{Pt}_{4}\end{array}$ & $\mathrm{Pt}$ \\
\hline $\begin{array}{l}\mathrm{O}_{2}{ }^{*} \\
+4\left(\mathrm{H}^{+}+\mathrm{e}^{-}\right)\end{array}$ & -0.08 & -0.10 & -0.18 & -0.80 & -0.78 & 0.14 & -0.81 & -0.91 & -0.63 \\
\hline $\begin{array}{l}\mathrm{O}_{2} *(\mathrm{TS}) \\
+4\left(\mathrm{H}^{+}+\mathrm{e}^{-}\right)\end{array}$ & 0.90 & 1.01 & 0.94 & -0.66 & -0.67 & 1.51 & -0.52 & -0.62 & -0.47 \\
\hline $\begin{array}{l}\mathrm{OOH}^{*} \\
+4\left(\mathrm{H}^{+}+\mathrm{e}^{-}\right)\end{array}$ & 0.27 & 0.28 & 0.18 & 0.01 & 0.00 & 0.50 & 0.08 & 0.06 & 0.15 \\
\hline $\begin{array}{l}\mathrm{OOH}^{*}(\mathrm{TS}) \\
+4\left(\mathrm{H}^{+}+\mathrm{e}^{-}\right)\end{array}$ & 0.60 & 0.48 & 0.43 & 0.01 & 0.00 & 0.85 & 0.27 & 0.29 & 0.32 \\
\hline $\begin{array}{l}2 \mathrm{O}^{*} \\
+4\left(\mathrm{H}^{+}+\mathrm{e}^{-}\right) \\
\end{array}$ & -1.26 & -1.14 & -1.32 & -2.22 & -2.34 & -0.25 & -2.24 & -2.35 & -1.85 \\
\hline $\begin{array}{l}\mathrm{O}^{*}+\mathrm{OH}^{*} \\
+3\left(\mathrm{H}^{+}+\mathrm{e}^{-}\right) \\
\end{array}$ & -1.50 & -1.43 & -1.60 & -2.12 & -2.19 & -0.75 & -2.01 & -2.09 & -1.80 \\
\hline $\begin{array}{l}2 \mathrm{OH}^{*} \\
+2\left(\mathrm{H}^{+}+\mathrm{e}^{-}\right)\end{array}$ & -1.74 & -1.72 & -1.89 & -2.02 & -2.04 & -1.24 & -1.79 & -1.83 & -1.76 \\
\hline $\begin{array}{l}\mathrm{OH}^{*}+\mathrm{H}_{2} \mathrm{O}(\mathrm{g}) \\
+\left(\mathrm{H}^{+}+\mathrm{e}^{-}\right)\end{array}$ & -1.53 & -1.51 & -1.60 & -1.67 & -1.67 & -1.28 & -1.31 & -1.57 & -1.54 \\
\hline
\end{tabular}


Table S11. Binding energies of adsorbed $\mathrm{O}^{*}$ and $\mathrm{OH}^{*}$, and activation energies for $\mathrm{O}^{-} \mathrm{O}$ bond-breaking in adsorbed $\mathrm{O}_{2} *$ and $\mathrm{OOH}^{*}$. All numerical values are given in $\mathrm{eV}$.

\begin{tabular}{|c|c|c|c|c|c|c|c|c|c|}
\hline Surface & $\operatorname{Ag}(100)$ & \multicolumn{2}{|c|}{$\operatorname{PtAg}_{3}(100)$} & \multicolumn{3}{|c|}{$\operatorname{PtAg}(100)$} & \multicolumn{2}{|c|}{$\mathrm{Pt}_{3} \mathrm{Ag}(100)$} & $\operatorname{Pt}(100)$ \\
\hline $\begin{array}{l}3^{\text {rd }} / 4^{\text {th }} \text { Layer } \\
\text { Composition }\end{array}$ & $\mathrm{Ag}$ & $\begin{array}{c}\mathrm{Ag}_{4} / \\
\mathrm{Pt}_{2} \mathrm{Ag}_{2}\end{array}$ & $\begin{array}{c}\mathrm{Pt}_{2} \mathrm{Ag}_{2} / \\
\mathrm{Ag}_{4}\end{array}$ & $\begin{array}{l}\mathrm{Ag}_{4} / \\
\mathrm{Pt}_{4}\end{array}$ & $\begin{array}{l}\mathrm{Pt}_{2} \mathrm{Ag}_{2} / \\
\mathrm{Pt}_{2} \mathrm{Ag}_{2}\end{array}$ & $\begin{array}{l}\mathrm{Pt}_{4} / \\
\mathrm{Ag}_{4}\end{array}$ & $\begin{array}{c}\mathrm{Pt}_{2} \mathrm{Ag}_{2} / \\
\mathrm{Pt}_{4}\end{array}$ & $\begin{array}{c}\mathrm{Pt}_{4} / \\
\mathrm{Pt}_{2} \mathrm{Ag}_{2}\end{array}$ & $\mathrm{Pt}$ \\
\hline $\begin{array}{l}\text { Preferred } \\
1^{\text {st }} / 2^{\text {nd }} \text { Layer } \\
\text { Composition }\end{array}$ & $\mathrm{Ag}$ & $\begin{array}{c}\mathrm{Ag}_{4} / \\
\mathrm{Pt}_{2} \mathrm{Ag}_{2}\end{array}$ & $\begin{array}{c}\mathrm{Ag}_{4} / \\
\mathrm{Pt}_{2} \mathrm{Ag}_{2}\end{array}$ & $\begin{array}{l}\mathrm{Pt}_{2} \mathrm{Ag}_{2} / \\
\mathrm{Pt}_{2} \mathrm{Ag}_{2}\end{array}$ & $\begin{array}{l}\mathrm{Pt}_{2} \mathrm{Ag}_{2} / \\
\mathrm{Pt}_{2} \mathrm{Ag}_{2}\end{array}$ & $\begin{array}{c}\mathrm{Ag}_{4} / \\
\mathrm{Pt}_{4}\end{array}$ & $\begin{array}{c}\mathrm{Pt}_{2} \mathrm{Ag}_{2} / \\
\mathrm{Pt}_{4}\end{array}$ & $\begin{array}{c}\mathrm{Pt}_{2} \mathrm{Ag}_{2} / \\
\mathrm{Pt}_{4}\end{array}$ & $\mathrm{Pt}$ \\
\hline $\mathrm{BE}\left(\mathrm{O}^{*}\right)$ & -3.96 & -3.90 & -3.99 & -4.49 & -4.51 & -3.45 & -4.47 & -4.52 & -4.28 \\
\hline $\mathrm{BE}\left(\mathrm{OH}^{*}\right)$ & -2.82 & -2.84 & -2.88 & -3.04 & -3.05 & -2.68 & -2.92 & -2.94 & -2.93 \\
\hline $\begin{array}{l}\mathrm{E}_{\mathrm{a}}: \mathrm{O}_{2} * \rightarrow \\
\mathrm{O}^{*}+\mathrm{O}^{*}\end{array}$ & 1.01 & 1.11 & 1.13 & 0.13 & 0.11 & 1.38 & 0.29 & 0.30 & 0.15 \\
\hline $\begin{array}{l}\mathrm{E}_{\mathrm{a}}: \mathrm{OOH}^{*} \rightarrow \\
\mathrm{O}^{*}+\mathrm{OH}^{*}\end{array}$ & 0.35 & 0.21 & 0.21 & 0.05 & 0.04 & 0.38 & 0.08 & 0.14 & 0.12 \\
\hline
\end{tabular}

